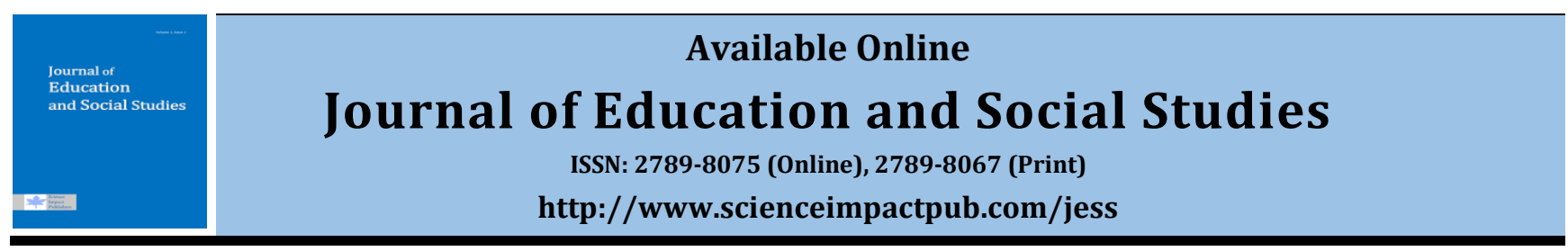

\title{
A STUDY OF TEACHERS VIEWS ABOUT THE STUDENTS OF NON-FORMAL INSTITUTES
}

\author{
Saima Riaz ${ }^{1, *}$ and Mudassar Yasin ${ }^{2}$ \\ ${ }^{1}$ School Education Department, Government of Punjab, Pakistan \\ ${ }_{2}^{2}$ Muhammad Nawaz Sharif University of Agriculture Multan, Pakistan
}

\section{ABSTRACT}

Education plays a very crucial role in the development of child's abilities, attitude, and behavior. It develops a positive change in the social life of the children. Therefore, many developed and developing nations highly encourage the spread of education through non-formal means. The non-formal education system is usually planned to provide effective knowledge and skills among the people. The present study was conducted with an aim to evaluate the views of non-formal institutions teachers about the students. This study was carried out in district Toba Tek Singh of Punjab province. The present study was descriptive in nature, and a survey was conducted to evaluate the non-formal education systems. All the non-formal educational institutions were the population of the study. The sample size of 50 teachers working in the non-formal educational institute of district Toba Tek Singh was chosen. The researcher for data collection developed a self-designed questionnaire. The collected data were analyzed through Statistical Package for Social Sciences (SPSS). The results of this study showed significant differences received from the respondents of non-formal education schools. The obtained results showed that respondents are getting good benefits from the non-formal education system. It is concluded from this study that education is very important for the development of any nation, and it is considered a fundamental human right.

Keywords: Non-formal education; Impact; Punjab.

Email:_saimariaz322@gmail.com

(C) The Author(s) 2021.

https://doi.org/10.52223/jess.20212205

This is an open access article under the CC BY license (http://creativecommons.org/licenses/by/4.0/).

\section{INTRODUCTION}

Education is very important for the development of any nation, and it is considered a fundamental human right. All children and people should have equal opportunities for education and learning. Pakistan is the $6^{\text {th }}$ largest country regarding a population (176 million) and the $2^{\text {nd }}$ most populous country in South Asia. About $61 \%$ of the people belong to a rural community. The literacy rate of Pakistan is about $54 \%$, of which $65.25 \%$ are men, and $41.75 \%$ are women. Whereas, in literacy rate in rural areas is at alarming situation especially for women that 29 percent. The main reason for this alarming situation in the very low literacy rate of rural areas is the result of low financial priority to the education sector and ill-judged Govt. educational policies in the country (Govt. of Pakistan, 2012). Hence, in a country like Pakistan, there is a need to make long-term educational reforms at the primary level to meet the desired education targets, minimize the rate of drop-outs at the school level, and ensure the quality of education. Though children who have never joined the formal education system or have dropped out, short-term solutions also need to provide basic educational opportunities. The National Commission on Human Development is establishing a network of community-based non-formal schools in the whole country. These communitybased non-formal schools are working as a support system and address the immediate needs of the education sector all over the country (Govt. of Pakistan, 2000). 
The non-formal educational system is planned and established by the education provider. Non-formal education is the addition, alternative, or complements to a formal education system that results in lifelong learning. Access to education for all is often provided the guarantee of a non-formal education system. Nonformal education may be short in duration or low intensity, and it is offered to people in various forms such as short courses, seminars, or workshops, and all ages of people can benefit from it. The non-formal educational system can cover those programs that contribute to the education for dropped out or children not coming to school and to literate the adults and youths as well as various other programs related to life skills, job skills, and social or cultural development (Unicef, 2013).

In the 1970s and 1980s, non-formal education has emerged as a massive outburst of interest worldwide, especially in developing nations (Rogers, 2004). But, in the late 1980s, this type of education diminished significantly when schooling was considered a dominant way of learning for international communities. However, in the equivalent, non-formal education has been highlighted less positively. Due to limited funding, non-formal education is comprised of small-scale and short-term programs that decrease its impact, effectiveness, and quality of education. These non-formal programs may not always be affiliated with wider educational and developmental policies at the national level, and in most cases, these programs do not persuade the learners to continue their formal education. Hence, non-formal education inclines to be apparent as slightly inferior as compared to formal education (Unicef, 2014). Therefore, the present study was conducted with the aim to evaluate the views of teachers regarding the students of non-formal institutions.

\section{MATERIALS AND METHODS}

The present is descriptive in nature and conducted with an aim to evaluate the impact of non-formal education systems. All the non-formal educational institutions were the population of the study. The nonformal institute of District Toba Tek Singh was selected as the target population. The sample size of 50 teachers were working in the non-formal educational institutions of the district. The researcher for data collection developed a self-designed questionnaire. The reliability and validity were checked through experts and non-sample population. The collected data were analyzed through Statistical Package for Social Sciences (SPSS).

\section{RESULTS AND DISCUSSION}

Education plays a crucial role in developing a child's abilities, attitude, and behavior. It develops a positive change in the social life of the children. Therefore, many developed and developing nations highly encourage the spread of education through non-formal means because there is less demand or scope for a formal education system. The non-formal education system is usually planned to provide effective knowledge and skills among the people. Hence education is the process of bringing change in the attitudes and behavior of the people and community.

Table 1. Do you properly motivate the students for a new lesson or activity?

\begin{tabular}{|l|c|c|c|}
\hline Levels & Frequency & Mean \\
\hline Strongly Disagree & 0 & 0 & \multirow{3}{*}{4.98} \\
\hline Disagree & 0 & 0 & \\
\hline Undecided & 0 & 0 & \\
\hline Agree & 1 & 9.0 & \\
\hline Strongly Agree & 49 & 100.0 & \\
\hline Total & 50 & & \\
\hline
\end{tabular}

The analyzed results presented in Table 1 show the variable response of teachers to motivate the students for new lessons or activities. The results indicate that all of the respondents are agreed that teachers properly motivate the students for new lessons or activities. The non-formal educational system is the 
pathway that categorized through higher grade of traceability. It widely opens the change and novelty in the society, teaching and various modes of delivery. Non-formal education provides the basic learning needs of children, adults, and young people all around the world. Therefore, a wide range of stakeholders (educational organizations, public and private institutes and NGOs) are deeply involved in the non-formal type of education system (Unicef, 2014). These projects are offered in the different states under the supervision of the state organizations for government-funded instruction. The open apprenticeship plot, working in the casual part, can supplement these projects with wage-producing professional abilities focused at annihilating destitution (All, 2007). Given the long lasting learning destinations of grown-up training, most underdeveloped nations utilize grown-up instruction to enhance education, to redesign word related skills, and for group advancement (Hiemstra, 2003).

Table 2. Do you give homework regularly to the students?

\begin{tabular}{|l|c|c|c|}
\hline Levels & Frequency & (\% age) & \\
\hline Strongly Disagree & 0 & 0 & \\
\hline Disagree & 0 & 0 & \multirow{2}{*}{4.92} \\
\hline Undecided & 0 & 0 & \\
\hline Agree & 4 & 8.0 & \\
\hline Strongly Agree & 46 & 92.0 & \\
\hline Total & 50 & 100.0 & \\
\hline
\end{tabular}

Views of teachers giving regular homework to their students is presented in Table 2. The results show variable agreement levels of teachers about regular homework to their students. The obtained results clearly indicate that all of the respondents expressed their views that they are agreed to give homework regularly to their students. Ololube \& Egbezor (2012)carried out a study and stated the role and significance of non-formal education for humans and nation development. Their results showed that a significant relationship was found between non-formal education and human and national development. They recommended that there is a need to authorize the specialized agencies that carry out the non-formal education programs in terms of mass literacy, adult and youth education. Jumani et al. (2011) specified that the limitations in financial resources raised the need for non-formal education in the rapidly increased population growth. Whereas, for increased human development, there is a need to provide education for all. Therefore, non-formal education is getting more and more popular because it is low-cost and has easy adaptability in nature according to the needs and requirements of people. He explained that non-formal education includes literacy classes, internships, in-service training schemes and extension work in various organizations (health, agriculture, women's interests and community).

Table 3. Is dropout rate of students is higher in non-formal schools as compared to formal schools?

\begin{tabular}{|l|c|c|c|}
\hline Levels & Frequency & (\% age $)$ & \multirow{2}{*}{4} \\
\hline Strongly Disagree & 0 & 0 & \\
\hline Disagree & 0 & 0 & \\
\hline Undecided & 0 & 0 & \\
\hline Agree & 21 & 42.0 & \\
\hline Strongly Agree & 29 & 58.0 & \\
\hline Total & 50 & 100.0 & \\
\hline
\end{tabular}

The analyzed data regarding the dropout rate of students in non-formal and formal schools are presented in Table 3. The dropout rate of students in non-formal and formal schools is interpreted on the basis of various agreement levels. It is clear from the results that all of the respondents were agreed regarding the dropout rate is higher in non-formal schools than in formal schools. Ihejirika (2000) indicated that non- 
formal education provides a selected type of learning, particularly to adults, youth or children. The nonformal education includes adult education, internships, continuing education, in-service programs, on-thejob training programs, personnel and professional development, refresher courses, staff development programs, and student and workers industrial training.

Table 4. Students writing, speaking and communication skills properly develop.

\begin{tabular}{|l|c|c|c|}
\hline Levels & Frequency & Mean \\
\hline Strongly Disagree & 0 & 0 & \\
\hline Disagree & 1 & 2.0 & \multirow{2}{*}{4.72} \\
\hline Undecided & 0 & 0 & \\
\hline Agree & 11 & 22.0 & \\
\hline Strongly Agree & 38 & 76.0 & \\
\hline Total & 50 & 100.0 & \\
\hline
\end{tabular}

The data regarding the views of teachers about the writing, speaking, and communication skills of students are depicted in Table 4. It is clear from the results that the vast majority of the respondents (98\%) agreed that students' writing, speaking, and communication skills are properly developed. Meanwhile, only 2 percent of the respondents disagreed that students' writing, speaking, and communication skills are not properly developed. At the present day, non-formal education plays a vital role in the changing and development of the educational system (Rogers, 2004; Hoppers, 2006; Rose, 2009; Unicef, 2013). Metz (1991) stated that a large number of the people in developing nations belong to the rural community that received poor or no educational and other facilities. In contrast, the fundamental needs of these rural people are education, health facilities, community improvement, educational and technical skills that can be easily happened with non-formal education. Hence, non-formal education is planned in such a conscious or systematic ways and organized learning and trainings that occur outside of the formal education system.

\section{CONCLUSIONS}

Education is the process of bringing change in the attitudes and behavior of the people and community. The non-formal education system is usually planned to provide effective knowledge and skills among the people who are out of the formal education system. It is concluded from this study that non-formal education is playing a vital role in Pakistan to educate the people.

\section{REFERENCES}

All, E. for. (2007). Education for All Global Monitoring Report 2008: Education for ALL by 2015. Will We Make It? Oxford University Press.

Govt. of Pakistan. (2000). EFA in Pakistan: The challenge within Govt. of Pakistan, World Education from on EFA, Dakar, Senegal, 26-28 April 2000.

Govt. of Pakistan. (2012). National Plan of action on education for all, Islamabad: Ministry of Education.

Hiemstra, R. (2003). Adult education: An overview. Retrieved April 11, 2012 from http://wwwdistance. syr.edu/aeoverview.html.

Hoppers, W. (2006). Non-Formal Education and Basic Education Reform: A Conceptual Review. ERIC.

Ihejirika, J. C. (2000). Fundamentals of adult education delivery: A sociological perspective Owerri. Springfield Publishers.

Jumani, N. B., Rahman, F., \& Bibi, K. (2011). Potential of Non Formal Basic Education in Promoting Women Education in Pakistan. Online Submission, 4(1), 17-32. 
Ololube, N. P., \& Egbezor, D. E. (2012). A critical assessment of the role/importance of non-formal education to human and national development in Nigeria: future trends. International Journal of Scientific Research in Education, 5(2), 71-93.

Rogers, A. (2004). Non-Formal Education: flexible schooling or participatory education? Hong Kong. Comparative Education Research Centre Publ., University of Hong Kong Publ.

Rose, P. (2009). NGO provision of basic education: alternative or complementary service delivery to support access to the excluded? Compare, 39(2), 219-233.

Unicef. (2013). Envisioning education in the post-2015 development agenda: Executive summary. Global thematic consultation on education in the post-2015 development agenda.

Unicef. (2014). Global initiative on out-of-school children: South Asia regional study, covering Bangladesh, India, Pakistan and Sri Lanka. Retrieved March, 22, 2015. 